\title{
Effect of Spacing on Seed Yield of Indigenous Rangeland and Forage Grass Species Grown under Drip Irrigation
}

\author{
Saleem K. Nadaf*, Safaa M. Al-Farsi, Saleh A. Al-Hinai, \\ Abdul Aziz S. Al-Harthi and Ahmed N. Al-Bakri \\ Seed and Plant Genetic Resources Laboratory, Plant Production Research Center, \\ Directorate General of Agriculture and Livestock Research, \\ Ministry of Agriculture, PO Box 50, PC 121, Sultanate of Oman

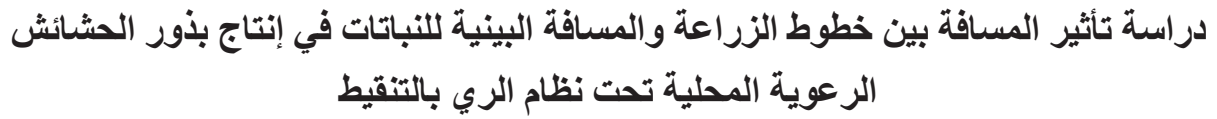 \\ سليم نداف وصفاء الفارسي و صالح الهنائي وعبدالعزيز الحارثي وأحمد البكري
}

\begin{abstract}
الخلاصة: ضمن المرحلة الأولى لبرنامج (ايكاردا) لثبه الجزيرة العربية تم در اسة نو عين من الأعشاب الرعوية و هي اللبيد و الاخنة و التي تم تجميعهما خلال برنامج الجمع القائم

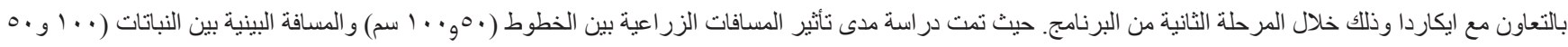

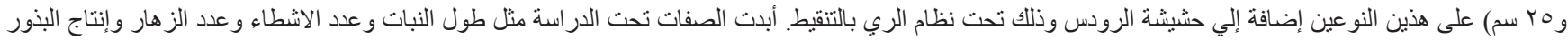

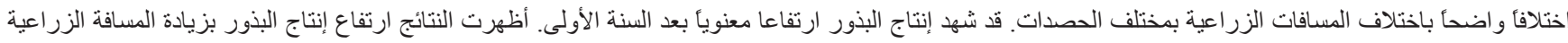

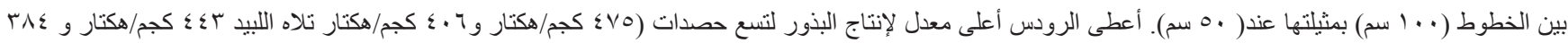

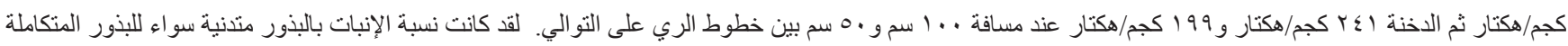

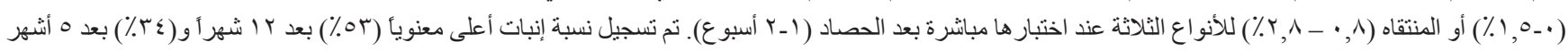

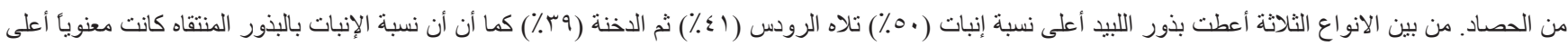

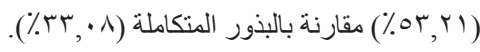

كلمات مفتاحية: الحشائش الرعوية ، المسافة بين خطوط الزر اعة ، مظاهر النمو ، انتاجية البذور ، الانبات ، سلطنة عمان.
\end{abstract}

\begin{abstract}
Two indigenous rangeland forage species, Cenchrus ciliaris and Coelachyrum piercei, were investigated for their response to varying inter-row $(50$ and $100-\mathrm{cm})$ and inter plant spacing $(25,50$ and $100-\mathrm{cm})$ under drip irrigation along with the perennial popular forage, Rhodes grass (Chloris gayana). Expression of traits, such as plant stand, plant height, number of tillers, number of panicles and seed yield, differed under varying inter-row and inter-plant spacing in different harvests. The grass species produced higher seed yield due to less interplant competition under wider $(100-\mathrm{cm})$ than under narrow row $(50-\mathrm{cm})$ spacing. Chloris gayana produced highest mean seed yield in wider inter-plant spacing (100-cm) under both inter-row spacings, viz. $100-\mathrm{cm}(488 \mathrm{~kg} / \mathrm{ha})$ and $50-\mathrm{cm}(449 \mathrm{~kg} / \mathrm{ha})$, followed by Cenchrus ciliaris (449 kg/ha under 100-cm and $377 \mathrm{~kg} / \mathrm{ha}$ under $50-\mathrm{cm}$ row spacing) and Coelachyrum piercei $(274 \mathrm{~kg} / \mathrm{ha}$ under $100-\mathrm{cm}$ and 210 $\mathrm{kg} / \mathrm{ha}$ under $50-\mathrm{cm}$ row spacing). In respect of seed quality for samples harvested selectively or in bulk, the three grasses showed very low germination when tested immediately (1-2 weeks) after harvest, not only for bulk seed ( 0 to $1.5 \%)$ but also for selected seed $(0.8 \%$ to $2.8 \%)$. Mean germination of grass species recorded after 12 months of harvests was significantly greater (53\%) than that recorded after 5 months ( $34 \%$ ) of harvests. Of the three grass species, Cenchrus ciliaris recorded significantly $(\mathrm{p}<0.01)$ highest germination \% $(50 \%)$ followed by Chloris gayana (41\%) and Coelachyrum piercei (39\%). Selected seeds had significantly ( $<0.01)$ higher germination (53\%) than bulk seeds $(33 \%)$.
\end{abstract}

Keywords: Grass species, Cenchrus ciliaris, Chloris gayana, Coelachyrum piercei, spacings, growth attributes, seed yield, germination, Sultanate of Oman.

\section{Introduction}

The Sultanate of Oman has a large area of rangelands especially in the Dhofar mountain areas of South Oman and the mountains of the North Oman. More than 90 germplasm samples of different indigenous forage species have been collected under the International Center for Agriculture Research in the Dry Areas (ICARDA) Arabian Peninsula Research Program (APRP) between 1998 and 2002. These are part of the local genetic diversity and are under use by 
Table 1. Values of some physical and chemical characteristics of the experimental soil at the Livestock Research Center, Rumais.

\begin{tabular}{llr}
\hline Chracteristics & & \\
\hline Physical: & & \\
& Coarse sand (\%) & 21.70 \\
& Fine sand (\%) & 63.00 \\
& Silt (\%) & 3.90 \\
& Clay (\%) & 11.40 \\
& Texture & Sand \\
Chemical: & & \\
& EC (1:5) dS & 5.70 \\
& pH (1:5) & 7.80 \\
& Soluble Cations (meq./100g) & 65.90 \\
& \multicolumn{2}{c}{ Na } \\
& K & 0.77 \\
& Soluble Anions (meq./100g) & \\
& Cl & 59.50 \\
& N (\%) & 0.04 \\
& Av.P (meq./100g) & 15.76 \\
\hline
\end{tabular}

grazing animals. Rangeland grass or pasture species appear to have been neglected as material for investigation, especially concerning the agronomic aspects of seed production. As grass species have evolved as perennials for vegetative forage yield, they have very low seed productivity (Chatterjee and Das, 1989 and Boonman, 1972). As such, the productivity and availability of seeds in the inflorescence per se at harvest have been observed to be important factors in the seed production of any grass species (Chatterjee and Das, 1989: Loch and Clark, 2000). Plant density is less meaningful in perennial pasture species as subsequent branching or tillering can compensate more rapidly for low plant density establishment. However, row spacing, continued cultivation and thinning of stands provide means of influencing shoot density (Humphreys, 1978).

Row culture has been recommended for many tropical pasture species. Owen (1951) found Paspalum dilatatum to give a seed yield of $182 \mathrm{~kg} / \mathrm{ha}$ in row culture as compared to $139 \mathrm{~kg} / \mathrm{ha}$ in broadcast swards. Some studies have demonstrated merits of low seeding rates or wide spacing for perennial grass seed crops (Evans, 1959 and 1962; Lambert, 1963). Low plant density tends to produce high fertility of tillers and more efficient seed production, since barren shoots contribute little to developing grain. On the other hand, in annual pasture crops like Stylosanthes humilis, Shelton and Humphreys (1971) found that the seed rate and the row spacing had special significance in balancing seed yield. Seed yield was highest to the extent of $690 \mathrm{~kg} / \mathrm{ha}$ at an optimum density $\left(850\right.$ plants $\left./ \mathrm{m}^{-2}\right)$, whereas both very low (10 to 250 plants/ $\mathrm{m}^{-2}$ ) and very high densities (3800 plants/ $\mathrm{m}^{-2}$ ) reduced seed yield.

Indigenous rangeland grass species, being more palatable for grazing animals and favoured by herders, are decreasing in the rangelands. In order to popularize these pasture species for cultivation under existing fodder production systems or re-vegetation of barren rangelands, seed production methods have to be standardized for specific irrigation system towards maximization of seed yield. Investigations were therefore undertaken over 2001-2003 under ICARDA-APRP in these two indigenous rangeland species and existing forage species under drip irrigation. The objective was to study the effect of interrow and inter-plant spacing on the seed yield and related characters and to select appropriate inter-row and inter plant spacings to produce maximum seed yield.

\section{Materials and Methods}

The grass species under study included two indigenous rangeland forage species, Buffel grass-Cenchrus ciliaris L. (UAE) and Coelachyrum piercei L. (UAE), collected under ICARDA-APRP Phase-I (Peacock et al., 2000) and Rhodes grass (Chloris gayana Kunth.)- Katambora. The trial was set out in a modified three factor Randomized Complete Block Design, with three replications involving three grass species as the first factor, two inter-row spacing (50 and $100-\mathrm{cm}$ ) as the second factor and three inter-plant spacing $(25,50$ and $100-\mathrm{cm})$ as the third factor. This was done under drip irrigation on a site consisting of sandy soil at Livestock Research Station, Rumais (Table 1). There were three and two four-meter rows per plot respectively at 50 and $100-\mathrm{cm}$ spacing.

Four to five seeds were sown just within $2.50 \mathrm{~cm}$ depth of sandy soil (Table 1) at drip points. Ten to fifteen granules of systemic insecticide, Carbofuron (Furadon) were broadcast around each hill to protect seeds from ants. The crop was fertilized with $150 \mathrm{~kg} \mathrm{~N}, 150 \mathrm{~kg} \mathrm{P}_{2} \mathrm{O}_{5}$ and $150 \mathrm{~kg} \mathrm{~K} \mathrm{~K}_{2} \mathrm{O}$ per hectare per year in the form of urea, triple super phosphate and potassium sulfate. The entire quantities of potassium and phosphate fertilizers were applied after the establishment of seedlings while $1 / 3 \mathrm{~N}$ was applied in two split doses $-1 / 2 \mathrm{~N}$ with $\mathrm{P}$ and $\mathrm{K}$ or after each harvest and remaining $1 / 2 \mathrm{~N}$ at flag leaf emergence. Nine seed harvests were taken up during the period of experimentation. The first harvest of the grass species was taken 125-135 days after seeding, whereas subsequent harvests were done at intervals of 60-70 days after visual confirmation of seed formation from the plot samples.

The data on five traits were recorded at harvest: plant stand (zero to 10 scale $(0-100 \%)$ ), plant height $(\mathrm{cm})$, number of tillers/ plant, number of panicles per plant and seed yield (with husk) (g) per plot ( $1 \mathrm{~m} \mathrm{x} 4 \mathrm{~m})$. These are considered as stable and reliable indicators of growth. The plant stand of each plot was scored on a recommended scale of zero to 10 , where score multiplied by 10 indicates plant stand in percentage. Plant height $(\mathrm{cm})$ from ground to tip of the panicle and number of panicles were recorded on five randomly selected plants, whereas seed yield was recorded from the plants of three random sites of $1 \mathrm{~m}^{2}$ in each plot.

The data were subjected to ANOVA considering harvests, inter-row spacing, inter-plant spacing and grass species as factors using the MSTAT-C computer program (Gomez and Gomez, 1984). The bulk seed and selected seed samples of each harvest were tested for germination 
using the Top of Paper (TP) method with five replications (Agrawal, 1980) not only at harvest but also after five and twelve months of each harvest. The data on germination were subjected to ANOVA, considering harvests, seed type, time of test and grass species as factors. The comparisons of means were made using corresponding LSD's for the factors and interactions whose effects were found significant.

\section{Results and Discussion}

Table 2 shows the ANOVA with respect to plant stand $(\%)$, plant height $(\mathrm{cm})$, number of tillers / plant, number of panicles / plant and seed yield ( $\mathrm{kg} / \mathrm{ha})$. In respect of plant stand the main effects of all factors and effects of 2- factor interactions (harvest $\mathrm{x}$ inter-row spacing, harvest $\mathrm{x}$ interplant spacing, harvest $\mathrm{x}$ grass species, inter-row spacing $\mathrm{x}$ grass species and inter-plant spacing $\mathrm{x}$ grass species) and that of one 3-factor interaction (such as harvest $\mathrm{x}$ inter-row spacing $\mathrm{x}$ grass species) were highly significant $(p<0.01)$. In the case of plant height, the main effects of all factors, effects of 2- factor interactions (harvest $\mathrm{x}$ interrow spacing, harvest $\mathrm{x}$ inter-plant spacing, harvest $\mathrm{x}$ grass species and inter-row spacing $x$ grass species), effects of two 3- factor interactions (harvest $\mathrm{x}$ inter-row spacing $\mathrm{x}$ grass species and inter-row spacing $\mathrm{x}$ inter-plant spacing $\mathrm{x}$ grass species) and also the effect of four factor interaction, were highly significant $(\mathrm{p}<0.05)$.

For number of tillers, the main effects of all factors and their interactions except the effects of one 2-factor interaction (harvests $\mathrm{x}$ inter-plant spacing) and one 3factor interaction (harvest $\mathrm{x}$ inter-plant spacing $\mathrm{x}$ grass species) and that of 4-factor interaction, were significant to a highly significant $(\mathrm{p}<0.01)$.

In number of panicles, effects of the main factors and effects of four 2- factor interactions (inter-row spacing $\mathrm{x}$ inter-plant spacing, harvests $\mathrm{x}$ grass species, inter-row spacing $\mathrm{x}$ grass species and inter-plant spacing $\mathrm{x}$ grass species) and also effects of two 3-factor interactions (harvest $\mathrm{x}$ inter-row spacing $\mathrm{x}$ grass species and inter-row spacing $x$ inter-plant spacing $x$ grass species) were highly significant $(\mathrm{p}<0.05)$. In respect of seed yield (with husk), all the main effects and all the effects of interactions, except that of two 2-factor interactions (inter-row spacing $\mathrm{x}$ inter-plant spacing and inter-row spacing $\mathrm{x}$ grass species), were highly significant $(\mathrm{p}<0.05)$ (Table 2$)$.

There was differential expression of the traits in the three grass species under varying inter-row and inter-plant spacing. Table 3 depicts the means over nine harvests of five characters studied under two inter-row and three interplant spacings. Only the significant interactions involving grass species with other factors have been discussed.

\section{Plant Stand (\%)}

Chloris gayana and Cenchrus ciliaris appeared more persistent as evidenced by higher mean plant stands over harvests during period of experimentation. Chloris gayana had significantly $(\mathrm{p}<0.05)$ higher mean plant stand
$(91.7 \%)$ than Cenchrus ciliaris $(88.1 \%)$ under inter-row spacing of $100-\mathrm{cm}$. However, there was no significant difference $(\mathrm{p}>0.05)$ between the plant stands of Chloris gayana $(90.7 \mathrm{~cm})$ and Cenchrus ciliaris $(90.8 \mathrm{~cm})$ under inter-row spacing of 50-cm (Table 3 ). Coelachyrum piercei was less persistent with low plant stands. In general, plant stands persistency of all grass species was of higher order under inter-row spacing of $100-\mathrm{cm}$. This is also evidenced by significantly $(\mathrm{p}<0.05)$ higher mean value of plant stands $(87.7 \%)$ found under inter-row spacing of $100-\mathrm{cm}$ than that under $50-\mathrm{cm}(82.6 \%)$ (Table 3$)$.

\section{Plant Height}

Among the grass species, both Cenchrus ciliaris and Chloris gayana had recorded mean plant height of over $100 \mathrm{~cm}$, significantly different $(\mathrm{p}<0.05)$ to Coelachyrum piercei (62.6 to $72.7 \mathrm{~cm}$ ) in both the row-spacings (Table 3). Cenchrus ciliaris had significantly higher mean plant height $(\mathrm{p}<0.05)$ of $114.5 \mathrm{~cm}$ at $100-\mathrm{cm}$ row spacing than at $50-\mathrm{cm}$ row spacing $(110.5 \mathrm{~cm})$. On the other hand, Chloris gayana had no differential response to two row-spacings $(p>0.05)$ in respect of plant height (Table 3). Interplant spacings had no significant effect in either of the row spacings with respect to mean plant height over harvests (Tables 2 and 3). Cenchrus ciliaris had significantly higher values of plant height under all interplant spacings in both the row spacings than Chloris gayana and Coelachyrum piercei. In respect of the effect of the row spacing, $100-\mathrm{cm}$ row spacing had significantly higher $(\mathrm{p}<0.05)$ mean plant height $(96.9 \mathrm{~cm})$ than $50-\mathrm{cm}(92.4 \mathrm{~cm})$ (Table 3$)$. There existed highly significant effects of 3-factor interaction involving grass species, row and plant spacings (Tables 2 and 3 ). As a result, Cenchrus ciliaris was found to show significantly $(p<0.05)$ the highest plant height in interplant spacing of $100 \mathrm{~cm}$ under both inter-row spacings viz. $100-\mathrm{cm}(115.5 \mathrm{~cm})$ and $50-\mathrm{cm}(113.8 \mathrm{~cm})$, followed by Chloris gayana that had $106.7 \mathrm{~cm}$ at $100-\mathrm{cm}$ and 104.6 $\mathrm{cm}$ at $50 \mathrm{~cm}$ row spacing (Table 3 ).

\section{Number of Tillers/Plant}

Among the grass species, there were differential patterns of tillering depending on row spacing. Cenchrus ciliaris excelled significantly $(\mathrm{p}<0.05)$ in tillering as compared to other two species and exhibited similar patterns of tillering, irrespective of row-spacing, as evidenced by the highest mean number of tillers found in 50-cm (101) and 100-cm (111) (Table 3). Conversely, Chloris gayana and Coelachyrum piercei exhibited differential tillering, depending on the row-spacing. Chloris gayana was able to produce more tillers, to the extent of 109 in wider $(100-\mathrm{cm})$ row-spacing than that (77 tillers) in narrow rowspacing $(50-\mathrm{cm})$, whereas Coelachyrum piercei showed heavy tillering (101 tillers) in narrow row-spacing while it was lower in tillering (86 tillers) in wider row-spacing. Among the row-spacings, the mean number of tillers in $100-\mathrm{cm}(102)$ was significantly $(\mathrm{p}<0.05)$ higher than in 50-cm (93). Among the inter-plant spacings, grasses 


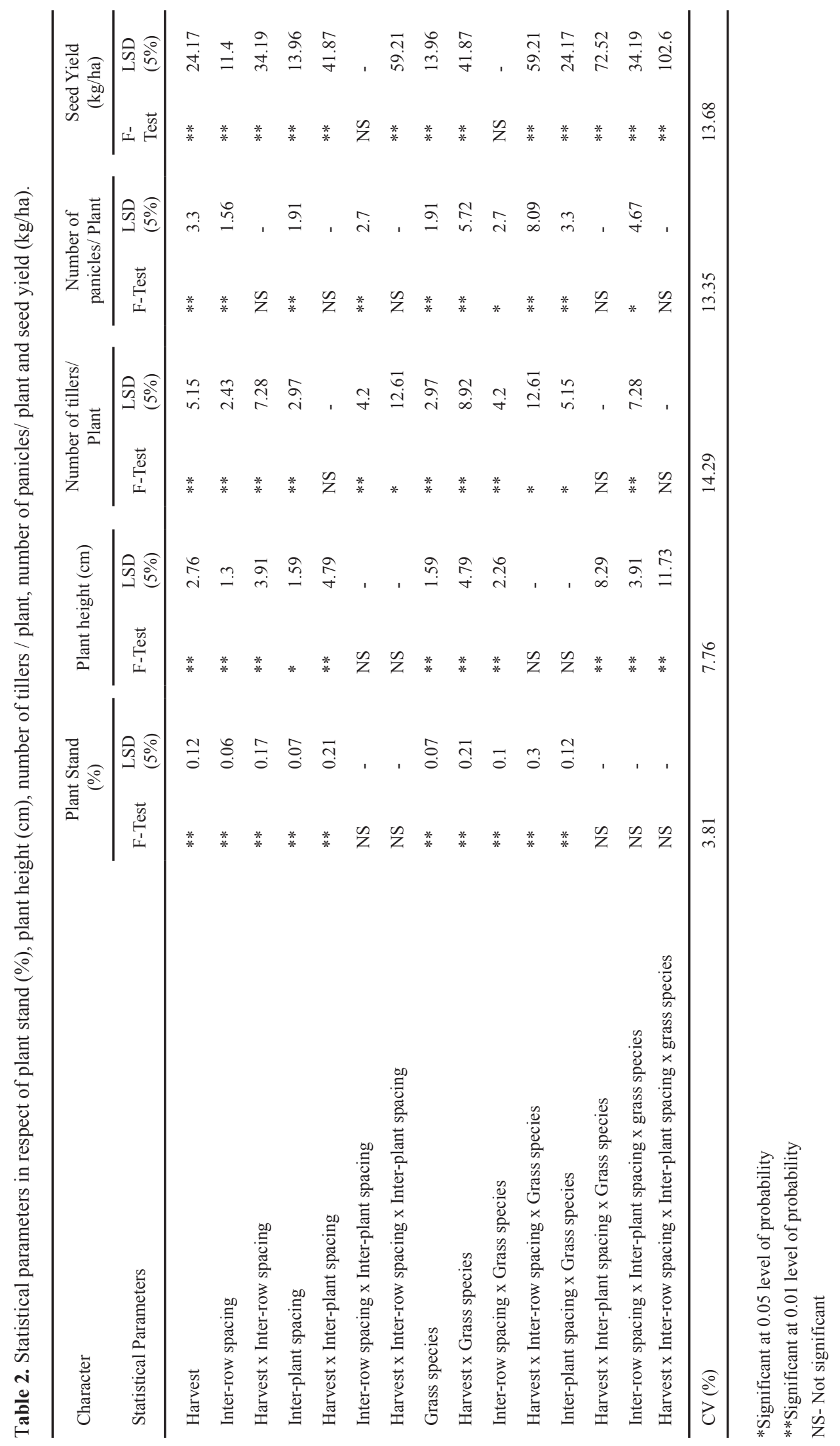




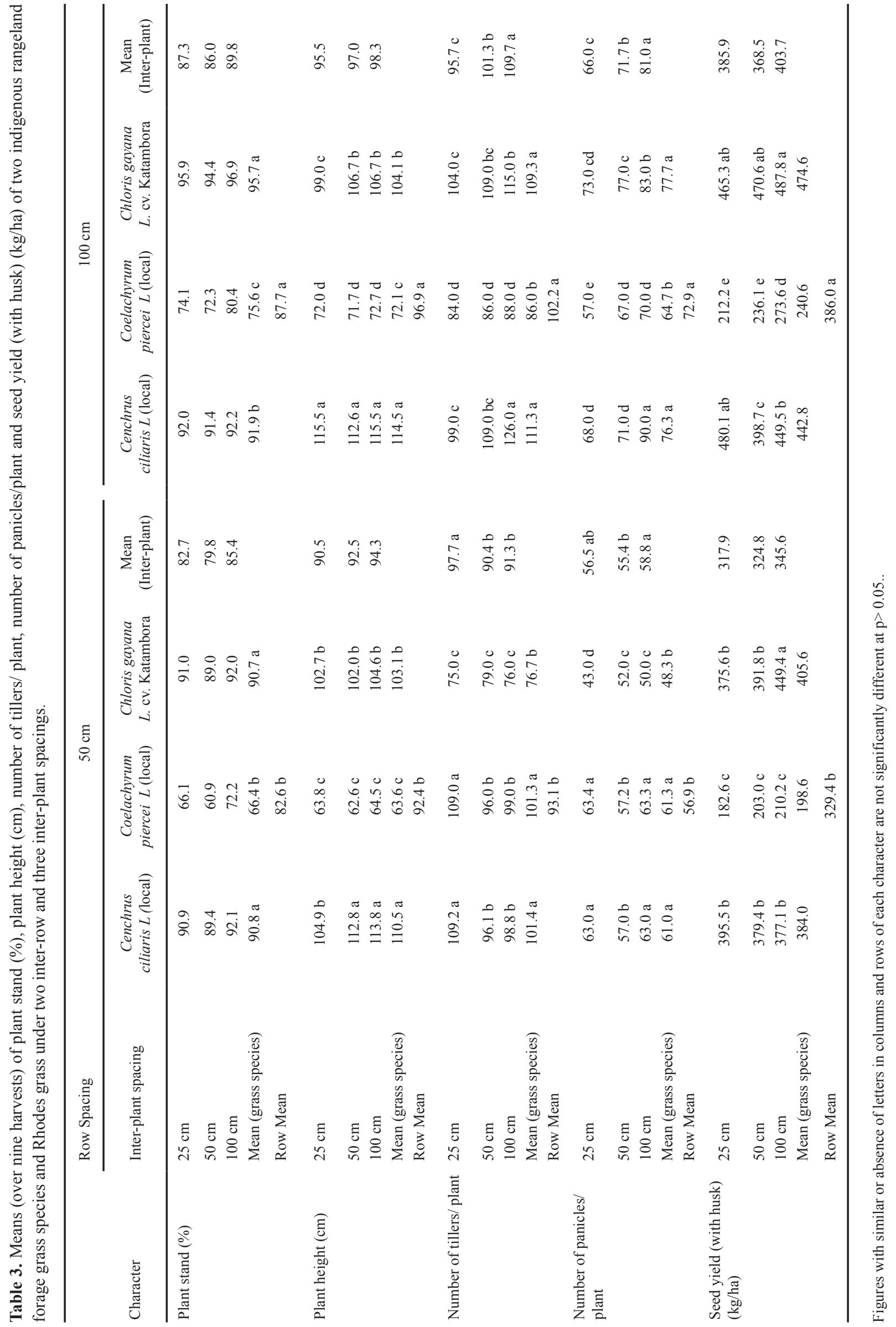


showed the significantly highest production of tillers in 25-cm spacing (98 tillers) as compared to others under 50$\mathrm{cm}$ row spacing, whereas the highest number of tillers was found in 100-cm inter-plant spacing (110 tillers). This was significantly different to the tillers produced in inter-plant spacings viz. $50-\mathrm{cm}$ (101 tillers) and $25-\mathrm{cm}$ (96 tillers). In respect of tillers, a high significant effect of 3-factor interaction was found involving grass species, row and plant spacings (Tables 2 and 3). As a result, Cenchrus ciliaris (109 tillers) and Coelachyrum piercei (109 tillers) were found to produce significantly $(p<0.05)$ more tillers in inter-plant spacing of $25 \mathrm{~cm}$ than in others under 50$\mathrm{cm}$ row-spacing where as Cenchrus ciliaris produced the significantly $(\mathrm{p}<0.05)$ highest number of tillers $(126)$ followed by Chloris gayana (115) in inter-plant spacing of $100 \mathrm{~cm}$ as compared to others (Table 3 ).

\section{Number of Panicles/Plant}

The mean number of panicles over nine harvests in wider row-spacing $(100-\mathrm{cm})$ was significantly $(\mathrm{p}<0.05)$ higher (73) than that (57) in narrow row-spacing $(50-\mathrm{cm})$ (Table 3). Chloris gayana and Cenchrus ciliaris produced significantly $(\mathrm{p}<0.05)$ more panicles to the extent of 78 and 76, respectively than Coelachyrum piercei (65) under wider row-spacing $(100-\mathrm{cm})$. On the other hand, Cenchrus ciliaris (61) and Coelachyrum piercei (61) produced significantly more panicles than Chloris gayana under narrow row-spacing $(50-\mathrm{cm})$. Among the interplant spacings, grasses showed the significantly highest production of panicles in $100-\mathrm{cm}$ spacing to the extent of 59 and 81 panicles, as compared to others, under 50 $\mathrm{cm}$ and $100-\mathrm{cm}$ row spacings, respectively. There was also a significant effect of 3-factor interaction involving grass species, row and plant spacings (Tables 2 and 3). As a result, Cenchrus ciliaris was found to produce significantly $(\mathrm{p}<0.05)$ more panicles $(63)$ in both interplant spacings of $25-\mathrm{cm}$ and $100-\mathrm{cm}$ under $50-\mathrm{cm}$ rowspacing, whereas Cenchrus ciliaris produced significantly $(\mathrm{p}<0.05)$ more panicles $(90)$, followed by Chloris gayana (83), in inter-plant spacing of $100 \mathrm{~cm}$, as compared to others (Table 3 ).

\section{Seed Yield (with husk)/ ha}

Mean seed yield of the grass species was significantly highest $(386.0 \mathrm{~kg} / \mathrm{ha})$ in wider row spacing $(100-\mathrm{cm})$ as compared to $329.4 \mathrm{~kg} / \mathrm{ha}$ in narrow row-spacing. The seed yield of three grass species and the seed yield in three inter-plant spacings were found to be not significant $(\mathrm{p}>0.05)$ under both row-spacings (Table 3 ) as 2 -factor interaction effects involving row-spacing and grass species, and row-spacing and inter-plant spacing were not significant $(\mathrm{p}>0.05)$ (Table 2$)$. However, there were significant $(p<0.05)$ effects of 3 -factor interaction involving grass species, row and plant spacings (Tables 2 and 3). As a result, Chloris gayana was found to produce the significantly $(\mathrm{p}<0.05)$ highest seed yield in inter-plant spacing $100-\mathrm{cm}$ to the extent of $449 \mathrm{~kg} / \mathrm{ha}$ and $488 \mathrm{~kg} / \mathrm{ha}$, followed by Cenchrus ciliaris that produced $377 \mathrm{~kg} / \mathrm{ha}$ and $449 \mathrm{~kg} / \mathrm{ha}$, respectively, under both $50-\mathrm{cm}$ and 100cm row-spacings (Table 3 ).

\section{Germination \%}

Table 4 shows germination percentage of bulk and selected seed samples of three grass species recorded after about five and twelve months of nine harvests along with relevant statistical parameters. The results indicated that the main effects all the factors, viz. harvests, seed type, time of test and grass species, effects of 2-factor interactions such as harvests $\mathrm{x}$ time of test, harvest $\mathrm{x}$ grass species and time of test $x$ grass species and a 3-factor interaction viz. harvests $\mathrm{x}$ time of test $\mathrm{x}$ grass species, were highly significant $(p<0.01)$. The results of germination reflect the quality of seed that could be produced in two kinds of harvest usually employed by seed growers: selective or bulk harvest. All three grass species showed very low germination \% when tested immediately (1-2 weeks) after harvest not only for bulk seed ( 0 to $1.5 \%$ ) but also for selected seed $(0.8 \%$ to $2.8 \%$ ). However, germination percentage was gradually improved further on storage at room temperature. This is evident by the fact that mean germination percentage of grass species recorded after 12 months of harvests was significantly $(\mathrm{p}<0.01)$ greater $(52.62 \%)$ than that recorded after 5 months (33.67\%) of harvests. This indicates that dormancy exists in freshly harvested grass seed, which gets broken down gradually depending upon the longevity of storage of seed.

Of the three grass species, Cenchrus ciliaris recorded significantly $(\mathrm{p}<0.01)$ the highest germination \% $(49.68 \%)$, followed by Chloris gayana (41.05\%) and Coelachyrum piercei $(38.71 \%)$. Selected seed had significantly $(\mathrm{p}<0.01)$ higher germination \% (53.21\%) than bulk seed (33.08\%) (Table 4). Lower germination percentage in bulk seed could be attributed to inclusion of immature seed of late formed panicles, possible loss of viable good quality seed due to shattering and possible loss of viability of a fraction of seed due to delay in harvesting the seed (Nadaf et al., 2004). This is not unexpected, as harvesting good quality seed is a major problem faced by grass seed growers. Grass seed growers often face substantial loss of good quality (viable) seeds while harvesting due to lack of knowledge about the appropriate harvesting time. It has been observed that some tropical grass species may produce good yields of seeds to the extent of $1000 \mathrm{~kg} / \mathrm{ha}$ and above, but only a small proportion (perhaps 5-7\% in Setaria anceps) is commercially recoverable (Chatterjee and Das, 1989).

In expanding the cultivation of perennial forage species, a limited supply of good seeds is an important constraint, which is also relevant to under-exploited indigenous rangeland pasture species. In developing better technology for seed production of pasture species, agronomic practices need to be devised which assist the seed producers to realize the yield potential of the rangeland pasture species. The results of the present investigation over nine harvests 
Table 4. Mean germination $\%$ of bulk and selected seed samples of three grass species recorded after five and twelve months of nine harvests.

\begin{tabular}{|c|c|c|c|c|c|c|c|c|c|c|c|c|c|}
\hline \multirow[b]{2}{*}{ Harvests } & \multirow{2}{*}{$\begin{array}{c}\text { Time of } \\
\text { Test } \\
\text { (After) }\end{array}$} & \multicolumn{3}{|c|}{ Cenchrus ciliaris } & \multicolumn{3}{|c|}{ Coelachyrum piercei } & \multicolumn{3}{|c|}{ Chloris gayana } & \multicolumn{3}{|c|}{ Mean over grass species } \\
\hline & & $\begin{array}{l}\text { Bulk } \\
\text { seed }\end{array}$ & $\begin{array}{l}\text { Selected } \\
\text { seed }\end{array}$ & Mean & $\begin{array}{l}\text { Bulk } \\
\text { seed }\end{array}$ & $\begin{array}{l}\text { Selected } \\
\text { seed }\end{array}$ & Mean & $\begin{array}{l}\text { Bulk } \\
\text { seed }\end{array}$ & $\begin{array}{l}\text { Selected } \\
\text { seed }\end{array}$ & Mean & $\begin{array}{l}\text { Bulk } \\
\text { seed }\end{array}$ & $\begin{array}{l}\text { Selected } \\
\text { seed }\end{array}$ & Mean \\
\hline \multirow{3}{*}{$\begin{array}{c}\text { I } \\
\text { Sept } 01\end{array}$} & $5 \mathrm{mo}$ & 28.20 & 48.10 & 38.15 & 25.20 & 45.30 & 35.25 & 18.35 & 38.15 & 28.25 & 23.92 & 43.85 & \multirow[b]{3}{*}{45.10} \\
\hline & $12 \mathrm{mo}$ & 58.27 & 78.27 & 68.27 & 43.27 & 63.27 & 53.27 & 37.37 & 57.37 & 47.37 & 46.30 & 66.30 & \\
\hline & Mean & 43.24 & 63.19 & 53.21 & 34.24 & 54.29 & 44.26 & 27.86 & 47.76 & 37.81 & 35.11 & 55.08 & \\
\hline \multirow{3}{*}{$\begin{array}{c}\text { II } \\
\text { Jan - Feb } 02\end{array}$} & $5 \mathrm{mo}$ & 26.25 & 46.25 & 36.25 & 23.56 & 43.56 & 33.56 & 22.75 & 42.75 & 32.75 & 24.19 & 44.19 & \multirow[b]{3}{*}{44.15} \\
\hline & $12 \mathrm{mo}$ & 49.35 & 69.35 & 59.35 & 34.33 & 54.33 & 44.33 & 48.66 & 68.66 & 58.66 & 44.11 & 64.11 & \\
\hline & Mean & 37.80 & $\mathbf{5 7 . 8 0}$ & 47.80 & 28.95 & 48.95 & 38.95 & 35.71 & 55.71 & 45.71 & 34.15 & 54.15 & \\
\hline \multirow{3}{*}{$\begin{array}{c}\text { III } \\
\text { Apr - May } \\
02\end{array}$} & $5 \mathrm{mo}$ & 31.21 & 51.11 & 41.16 & 26.32 & 46.15 & 36.24 & 21.35 & 41.33 & 31.34 & 26.29 & 46.20 & \multirow[b]{3}{*}{44.02} \\
\hline & $12 \mathrm{mo}$ & 50.38 & 70.38 & 60.38 & 31.67 & 51.67 & 41.67 & 49.33 & 69.33 & 59.33 & 43.79 & 63.79 & \\
\hline & Mean & 40.80 & 60.75 & 50.77 & 29.00 & 48.91 & 38.95 & 35.34 & 55.33 & 45.34 & 35.04 & 55.00 & \\
\hline \multirow{3}{*}{$\begin{array}{c}\text { IV } \\
\text { Jul - Aug } 02\end{array}$} & $5 \mathrm{mo}$ & 27.25 & 47.13 & 37.19 & 19.35 & 39.22 & 29.29 & 17.36 & 37.31 & 27.34 & 21.32 & 41.22 & \multirow{3}{*}{42.33} \\
\hline & $12 \mathrm{mo}$ & 61.32 & 81.32 & 71.32 & 28.13 & 48.13 & 38.13 & 40.67 & 60.67 & 50.67 & 43.37 & 63.37 & \\
\hline & Mean & 44.29 & 64.23 & 54.26 & 23.74 & 43.68 & 33.71 & 29.02 & 48.99 & 39.00 & 32.35 & 52.30 & \\
\hline \multirow{3}{*}{$\begin{array}{c}\text { V } \\
\text { Oct - Nov } 02\end{array}$} & $5 \mathrm{mo}$ & 26.75 & 46.33 & 36.54 & 24.36 & 44.15 & 34.26 & 19.25 & 39.27 & 29.26 & 23.45 & 43.25 & \multirow[b]{3}{*}{43.38} \\
\hline & $12 \mathrm{mo}$ & 52.67 & 72.67 & 62.67 & 39.19 & 59.19 & 49.19 & 38.33 & 58.33 & 48.33 & 43.40 & 63.40 & \\
\hline & Mean & 39.71 & $\mathbf{5 9 . 5 0}$ & 49.61 & 31.78 & 51.67 & 41.72 & 28.79 & 48.80 & 38.80 & 33.43 & 53.32 & \\
\hline \multirow{3}{*}{$\begin{array}{c}\text { VI } \\
\text { Jan - Feb } 03\end{array}$} & $5 \mathrm{mo}$ & 29.05 & 49.20 & 39.13 & 22.58 & 42.41 & 32.50 & 22.55 & 42.15 & 32.35 & 24.73 & 44.59 & \multirow[b]{3}{*}{43.54} \\
\hline & $12 \mathrm{mo}$ & 48.32 & 68.32 & 58.32 & 35.13 & 55.13 & 45.13 & 43.79 & 63.79 & 53.79 & 42.41 & 62.41 & \\
\hline & Mean & 38.69 & 58.76 & 48.72 & 28.86 & 48.77 & 38.81 & 33.17 & 52.97 & 43.07 & 33.57 & 53.50 & \\
\hline \multirow{3}{*}{$\begin{array}{c}\text { VII } \\
\text { Apr - May } \\
03\end{array}$} & $5 \mathrm{mo}$ & 28.75 & 48.53 & 38.64 & 24.62 & 44.15 & 34.39 & 20.36 & 40.33 & 30.35 & 24.58 & 44.34 & \multirow[b]{3}{*}{40.66} \\
\hline & $12 \mathrm{mo}$ & 37.93 & 67.93 & 52.93 & 28.33 & 48.33 & 38.33 & 39.33 & 59.33 & 49.33 & 35.20 & 58.53 & \\
\hline & Mean & 33.34 & 58.23 & 45.79 & 26.48 & 46.24 & 36.36 & 29.85 & 49.83 & 39.84 & 29.89 & 51.43 & \\
\hline \multirow{3}{*}{$\begin{array}{c}\text { VIII } \\
\text { July - Aug } \\
03\end{array}$} & $5 \mathrm{mo}$ & 24.26 & 44.15 & 34.21 & 18.79 & 38.24 & 28.52 & 19.33 & 39.46 & 29.40 & 20.79 & 40.62 & \multirow[b]{3}{*}{39.95} \\
\hline & $12 \mathrm{mo}$ & 52.68 & 72.68 & 62.68 & 27.17 & 47.17 & 37.17 & 37.69 & 57.69 & 47.69 & 39.18 & 59.18 & \\
\hline & Mean & 38.47 & 58.42 & 48.44 & 22.98 & 42.71 & 32.84 & 28.51 & 48.58 & 38.54 & 29.99 & 49.90 & \\
\hline \multirow{3}{*}{$\begin{array}{c}\text { IX } \\
\text { Oct - Nov } 03\end{array}$} & $5 \mathrm{mo}$ & 27.02 & 47.08 & 37.05 & 23.99 & 43.63 & 33.81 & 22.03 & 42.14 & 32.09 & 24.35 & 44.28 & \multirow[b]{3}{*}{44.24} \\
\hline & $12 \mathrm{mo}$ & 49.98 & 69.98 & 59.98 & 41.79 & 61.79 & 51.79 & 40.67 & 60.67 & 50.67 & 44.15 & 64.15 & \\
\hline & Mean & 38.50 & 58.53 & 48.52 & 32.89 & 52.71 & 42.80 & 31.35 & 51.41 & 41.38 & 34.25 & 54.22 & \\
\hline \multirow{2}{*}{$\begin{array}{c}\text { Mean over } \\
\text { Harvests }\end{array}$} & $5 \mathrm{mo}$ & 27.64 & 47.54 & 37.59 & 23.20 & 42.98 & 33.09 & 20.37 & 40.32 & 30.35 & 23.73 & 43.61 & 33.67 \\
\hline & $12 \mathrm{mo}$ & 51.21 & 72.32 & 61.77 & 34.33 & 54.33 & 44.33 & 41.76 & 61.76 & 51.76 & 42.44 & 62.81 & 52.63 \\
\hline Mean & \multicolumn{4}{|c|}{49.68} & & 21 & & & 05 & & 33.08 & 53.21 & \\
\hline
\end{tabular}

Statistical Parameters:

\begin{tabular}{|c|c|c|c|c|c|}
\hline & F-test & LSD (at 5\% level) & & F-test & LSD (at $5 \%$ level) \\
\hline Harvests & ** & 1.67 & Harvests $x$ Grass species & ** & 2.90 \\
\hline Seed type & ** & 0.79 & Seed type $\mathrm{x}$ Grass species & NS & - \\
\hline Harvests $x$ Seed type & NS & - & Harvests $\mathrm{x}$ Seed type $\mathrm{x}$ Grass species & NS & - \\
\hline Time of test & ** & 0.79 & Time of test $x$ Grass species & ** & 1.36 \\
\hline Harvests $x$ Time of test & $* *$ & 2.36 & Harvests $x$ Time of test $x$ Grass species & ** & 4.09 \\
\hline Seed type $\mathrm{x}$ Time of test & NS & - & Seed type $x$ Time of test $x$ Grass species & NS & - \\
\hline Harvests $\mathrm{x}$ Seed type $\mathrm{x}$ Time of test & NS & - & Harvests $\mathrm{x}$ Seed type $\mathrm{x}$ Time of test $\mathrm{x}$ Grass species & NS & - \\
\hline Grass species & ** & 0.96 & CV (\%) & 8.38 & \\
\hline
\end{tabular}


indicate that the grass species behave differentially for their optimum performance in varying inter-row and inter-plant spacing. This is particularly true for seed yield (Table 3). Wider inter-row spacing significantly $(\mathrm{p}<0.05)$ influenced formation of more panicles and higher seed yield, irrespective of grass species (Table 3). Chatterjee and Das (1989) also speculated that in grass species like Cenchrus ciliaris, seed crop sown in wider spacing produces greater seed yield.

In the case of perennial pasture species, low plant density at establishment results in higher plant densities later on. The low plant density in the beginning would lead to high percentage fertility of tillers as each hill of grass has less or an absence of interplant competition (Chatterjee and Das, 1989 and Young III et al., 1998). In the present study, Cenchrus ciliaris and Rhodes grass (Chloris gayana), exhibited varying seed yields in the two inter-row spacings in most of the harvests, perhaps due to differential response of species to inter-plant competition. Conversely, Boonman (1972) observed that seed yield was independent of row spacing in Chloris gayana cv. Mbarara. In the perennial pastures, however, optimum plant density and row spacing are influenced by plant cultivar, soil fertility, moisture supply and age of plant stand.

The seed yield (with husk) levels of Chloris gayana and Cenchrus ciliaris found in the present study are comparable with the seed yield levels reported elsewhere. Skerman and Rivoros (1989) reported clean (naked) seed yield of 100-650 and 10-60 kg/ha in respect of Chloris gayana and Cenchrus ciliaris, respectively, and Chatterjee and Das (1989) reported seed yield (naked) of 500 to 600 and $100-200 \mathrm{~kg} / \mathrm{ha}$ in respect of Chloris gayana and Cenchrus ciliaris, respectively.

\section{Acknowledgements}

We are grateful to the Director General of Agriculture and Livestock Research and Director of Plant Production Research Center, for their assistance and encouragement in conducting experiments. APRP-ICARDA is gratefully acknowledged for financial and technical assistance.

\section{References}

Agrawal, R.L. 1980. Seed Technology. Oxford and IBH Pub. Co., 449-474.

Boonman, J.G. 1972. In : Chatterjee, B.N. and P.K. Das. 1989. Forage Crop Production - Principles and Practices. Oxford and IBH Pub. Co. Pvt. Ltd. New Delhi. 450p.
Chatterjee, B.N. and P.K. Das. 1989. Forage Crop Production - Principles and Practices. Oxford and IBH Pub. Co. Pvt. Ltd. New Delhi. 450p.

Evans, G. 1959. Seed rates of grasses for seed production. Pasture varieties of rye grass, cocksfoot and timothy. Empirical Journal of Experimental Agriculture 27:291.

Evans, G. 1962. Seed rates of grasses for seed production. II. Breed varieties of tall fescue, meadow fescue, cocksfoot (hey type), and Phalaris hybrid. Empirical Journal of Experimental Agriculture 30:181.

Gomez, K.A. and A.A. Gomez. 1984. Statistical Procedures for Agricultural Research. Second Edition. The International Rice Research Institute, Philippines.

Humphreys, I.R. 1978. Tropical Pasture Seed Production. FAO Plant Production and Protection Paper. Food and Agriculture Organization of the United Nations. Rome. pp 39-42.

Lambert, D.A. 1963. The influence of density and nitrogen in seed production stands of S37 cocksfoot (Dactylis glomerata L.). Journal of Agricultural Science 61:361.

Loch, D.S. and M. Clark. 2000. Production, harvesting and processing of native grass and herbaceous legume seeds: The reality and the challenge. First Regional Technical Coordination Meeting (RTCM). APRP Phase II. Dubai, UAE. 16-18 October 2000.

Nadaf, S.K., S.M. Al-Farsi and S.A. Al-Hinai. 2004. Seed multiplication of rangeland forage species in the Sultanate of Oman. Seed Information 27:12-14.

Owen, C.R. 1951. Improvement of native dallies grass in Louisiana. Louisiana Agri. Exp.Sta. Bull. 449:24.

Peacock, J.M., M.E. Ferguson, G.A. Alhadrami, I.R. McCann, A. Al Hajoj, A. Saleh and R. Karnik. 2000. Conservation through utilization - a case study of the indigenous forage grasses of the Arabian Peninsula. Paper Presented at the International Conference on the Conservation of Biodiversity in the Arid Regions. Kuwait. March 27-29, 2000.

Shelton, H.M. and L.R. Humhreys. 1971. Effect of variation in density and phosphate supply on seed production of Stylosanthes humilis. Journal of Agricultural Science, Cambridge, 76:325-336.

Skerman, P.J. and F. Riveros. 1989. Tropical Grasses. FAO Plant Production and Protection Series, No. 23. pp 266-274 and 283-288.

Young III, W.C., H.W. Youngberg and T.B. Silberstein. 1998. Management studies on seed production of turftype tall fescue: II. Seed yield components. Agronomy Journal 90:478-483.

Received: March 2005

Accepted: May 2007 